\title{
DAMPAK KULIAH KEWIRAUSAHAAN TERHADAP SIKAP DAN MOTIVASI MAHASISWA DALAM BERWIRAUSAHA
}

\author{
Dyah Fitriani \\ Universitas Ahmad Dahlan \\ e-mail:dhifa_dhe@yahoo.com
}

\begin{abstract}
ABSTRACK
This study analyze the effect of students' perceptions to the attitudes and motivations to become entrepreneurs. In addition, this study also analyze the influence of the advantages of entrepreneurship and entrepreneurial barriers to student interest in entrepreneurship. The sample was students who have taken courses in Entrepreneurship Management Department. The sampling technique used was purposive random sampling. Partial least square (PLS) used to analyze data.The results of this study were 1) there is a significant effect between perception and benefits of entrepreneurship to entrepreneurship motivation, 2) there is no significant effect between students' perceptions of the attitudes to entrepreneurship, 3) there is no significant effect between entrepreneurship constraints on entrepreneurship motivation, and 4) there is a significant effect between motivation towards entrepreneurship attitude.
\end{abstract}

Keywords: perception, attitude, motivation, benefits, barriers

\section{PENDAHULUAN}

Kewirausahaan menjadi topik penting pada beberapa tahun terakhir. Bahkan saat ini banyak perguruan tinggi yang membekali mahasiswanya dengan wawasan kewirausahaan supaya mereka dapat menciptakan lapangan kerja sendiri sehingga angka penggangguran yang berdampak pada meningkatnya jumlah kemiskinan dapat dikurangi. Selain pengetahuan mengenai kewirausahaan, perguruan tinggi juga membekali mahasiswa dengan softskill sesuai dengan tuntutan dunia kerja saat ini. Dengan demikian diharapkan lulusan perguruan tinggi memiliki kemampuan yang sesuai dengan tuntutan industri dan persaingan bisnis pada saat ini. Kemampuan untuk menciptakan ideide baru, kemampuan menyelesaikan masalah, keberanian untuk bertindak dan rasa pantang menyerah merupakan contoh aspek-aspek yang akan mempengaruhi keberhasilan atau kesuksesan seorang wirausaha. Kesuksesan seorang wirausaha juga dipengaruhi oleh sikap dan motivasi mereka dalam berwirausaha. Minat berwirausaha ternyata juga dipengaruhi oleh faktor latar belakang keluarga, pendidikan, dan pengalaman kerja. Seseorang yang memiliki keturunan pengusaha akan mengenal konsep berbisnis sejak mereka kecil. Pendidikan kewirausahaan secara tidak langsung diajarkan oleh orang tua selama anak tersebut tinggal bersama orang tua. Ketidakpuasan atas pekerjaan saat ini atau di masa lalu juga memicu beberapa orang untuk mulai menjadi wirausaha sehingga tidak menggantungkan hidupnya lagi pada orang lain.

Seseorang termotivasi akan sesuatu pasti disebabkan oleh beberapa faktor antara lain karena keuntungan-keuntungan yang mereka akan dapatkan setelah melakukan kegiatan 
tersebut. Tetapi perlu diingat bahwa dalam upaya pencapaian keuntungan tersebut pasti akan mengalami banyak kendala yang dihadapi (Zimmerer, 2001: 6).

Peranan Universitas dalam memotivasi sarjana menjadi wirausahawan muda sangat penting dalam menumbuhkan jumlah wirausahawan. Dengan meningkatnya wirausahawan dari kalangan sarjana akan mengurangi pertambahan jumlah pengangguran bahkan menambah jumlah lapangan pekerjaan. Peran universitas dijelaskan oleh beberapa pendapat para ahli bidang kewirausahaan .Salah satunya dijelaskan oleh Thomas Zimmerer bahwa salah satu faktor pendorong pertumbuhan kewirausahaan adalah pendidikan kewirausahaan. Selain itu Douglas A.Gray menyarankan untuk memulai usaha sejak dini misalnya pada waktu masih kuliah. Pihak Universitas bertanggung jawab dalam mendidik dan memberikan kemampuan dalam melihat peluang bisnis serta mengelola bisnis tersebut serta memberikan motivasi untuk mempunyai keberanian menghadapi resiko bisnis.

Perumusan masalah penelitian ini sebagai berikut: (1) Apakah persepsi mahasiswa akan mata kuliah kewirausahaan secara signifikan mempengaruhi sikap entrepreneur mahasiswa?, (2) Apakah persepsi mahasiswa akan mata kuliah kewirausahaan secara signifikan mempengaruhi motivasi mahasiswa untuk menjadi entrepreneur?, (3) Apakah keuntungan kewirausahaan secara signifikan mempengaruhi motivasi mahasiswa untuk menjadi entrepreneur?, (4) Apakah kendala berwirausaha secara signifikan mempengaruhi motivasi mahasiswa untuk menjadi entrepreneur?, (5) Apakah motivasi mahasiswa secara signifikan mempengaruhi sikap entrepreneur mahasiswa?, (6) Bagaimanakah persepsi mahasiswa akan mata kuliah kewirausahaan?, (7) Keuntungan kewirausahaan apa sajakah yang menarik minat mahasiswa untuk berwirausaha?, dan (8) Faktor apa sajakah yang menjadi kekhawatiran mahasiswa untuk menjadi entrepreneur?

\section{REVIEW LITERATUR DAN HIPOTESIS}

\section{Persepsi}

Persepsi adalah suatu proses yang ditempuh individu-individu untuk mengorganisasikan dan menafsirkan kesan-kesan indera mereka agar memberikan makna bagi lingkungan mereka (Robbins,2001:88).

Menurut Muhyadi (1989) persepsi seseorang dalam menangkap informasi dan peristiwa-peristiwa dipengaruhi oleh tiga faktor, yaitu : orang yang membentuk persepsi, stimulus yang berupa obyek maupun peristiwa tertentu, dan stimulasi dimana pembentukan persepsi itu terjadi baik tempat, waktu maupun suasana. Sedangkan Siagian (1995) mengemukakan bahwa komponen-komponen yang mempengaruhi persepsi ada tiga faktor, yaitu: pertama, pelaku persepsi. apabila seorang individu memandang suatu obyek dan mencoba menafsirkan apa yang dilihatnya, penafsiran itu sangat dipengaruhi oleh karakteristik pribadi dari pelaku persepsi individu itu, seperti sikap, motif, kepentingan, minat, pengalaman dan harapan. Kedua, sasaran/obyek. Karakteristik dari target yang akan diamati dapat mempengaruhi apa yang dipersepsikan, sasaran itu mungkin berupa orang, benda atau peristiwa. Dan ketiga, situasi. Unsur lingkungan sekitarnya bisa mempengaruhi persepsi kita. Jadi persepsi harus dilihat secara kontekstual, artinya dalam situasi mana persepsi itu timbul perlu mendapat perhatian.

Feldman (1990) mengemukakan bahwa komponen persepsi terdiri atas tiga indikator, yaitu : pelaku persepsi, sasaran persepsi, dan situasi dimana dilakukan persepsi. Hampir sama dengan apa yang dikemukakan Feldman, Robbins (1998) mengemukakan bahwa faktor-faktor yang mempengaruhi persepsi, yaitu :

a. pelaku persepsi, karena dipengaruhi oleh karakteristik individu yang turut berpengaruh seperti sikap, motif, kepentingan, minat, pengalaman dan harapan 
b. obyek/ target yang dipersepsikan, misalnya penampilan yang mencolok lebih menarik perhatian,

c. situasi dimana persepsi itu dilakukan (www. indoskipsi.com)

\section{Sikap}

Sikap (attitude) merupakan pernyataan penilaian terhadap yang disukai dan tidak disukai mengenai benda, orang, atau kejadian. Sikap juga merupakan pencerminan bagaimana perasaan seseorang terhadap sesuatu (Robbins, 2003:71).

Sarnoff (2000) mengidentifikasikan sikap sebagai kesediaan untuk bereaksi (disposition to react) secara positif (favorably) atau secara negatif (unfavorably) terhadap obyek - obyek tertentu. D.Krech dan R.S Crutchfield (1999) berpendapat bahwa sikap sebagai organisasi yang bersifat menetap dari proses motivasional, emosional, perseptual, dan kognitif mengenai aspek dunia individu. Sedangkan La Pierre (2003) memberikan definisi sikap sebagai suatu pola perilaku, tendensi atau kesiapan antisipatif, predisposisiuntuk menyesuaikan diridalam situasi sosial, atau secara sederhana, sikap adalah respon terhadap stimuli sosial yang telah terkondisikan. Lebih lanjut Soetarno (1994) memberikan definisi sikap adalah pandangan atau perasaan yang disertai kecenderungan untuk bertindak terhadap obyek tertentu. Sikap senantiasa diarahkan kepada sesuatu artinya tidak ada sikap tanpa obyek. Sikap diarahkan kepada benda-benda, orang, peritiwa, pandangan, lembaga, norma dan lain-lain. Meskipun ada beberapa perbedaan pengertian sikap, tetapi berdasarkan pendapatpendapat tersebut di atas maka dapat disimpulkan bahwa sikap adalah keadaan diri dalam manusia yang menggerakkan untuk bertindak atau berbuat dalam kegiatan sosial dengan perasaan tertentu di dalam menanggapi obyek situasi atau kondisi di lingkungan sekitarnya. Selain itu sikap juga memberikan kesiapan untuk merespon yang sifatnya positif atau negatif terhadap obyek atau situasi. (www.duniapsikologi.com)
Diantara berbagai faktor yang mempengaruhi pembentukan sikap adalah:

a. Pengalaman pribadi

Untuk dapat menjadi dasar pembentukan sikap, pengalaman pribadi harus meninggalkan kesan yang kuat. Karena itu, sikap akan lebih mudah terbentuk apabila pengalaman pribadi tersebut melibatkan faktor emosional. Dalam situasi yang melibatkan emosi, penghayatan akan pengalaman akan lebih mendalam dan lebih lama berbekas.

b. Kebudayaan

B.F. Skinner (2005) menekankan pengaruh lingkungan (termasuk kebudayaan) dalam membentuk kepribadian seseorang. Kepribadian tidak lain daripada pola perilaku yang konsisten yang menggambarkan sejarah reinforcement (penguatan, ganjaran) yang dimiliki. Pola reinforcement dari masyarakat untuk sikap dan perilaku tersebut, bukan untuk sikap dan perilaku yang lain.

c. Orang lain yang dianggap penting Pada umumnya, individu bersikap konformis atau searah dengan sikap orang orang yang dianggapnya penting. Kecenderungan ini antara lain dimotivasi oleh keinginan untuk berafiliasi dan keinginan untuk menghindari konflik dengan orang yang dianggap penting tersebut.

d. Media massa

Sebagai sarana komunikasi, berbagai media massa seperti televisi, radio, mempunyai pengaruh besar dalam pembentukan opini dan kepercayaan orang. Adanya informasi baru mengenai sesuatu hal memberikan landasan kognitif baru bagi terbentuknya sikap terhadap hal tersebut. Pesan-pesan sugestif yang dibawa informasi tersebut, apabila cukup kuat, akan memberi dasar afektif dalam mempersepsikan dan menilai sesuatu hal sehingga terbentuklah arah sikap tertentu. 
e. Institusi Pendidikan dan Agama

Sebagai suatu sistem, institusi pendidikan dan agama mempunyai pengaruh kuat dalam pembentukan sikap dikarenakan keduanya meletakkan dasar pengertian dan konsep moral dalam diri individu. Pemahaman akan baik dan buruk, garis pemisah antara sesuatu yang boleh dan tidak boleh dilakukan, diperoleh dari pendidikan dan dari pusat keagamaan serta ajaran-ajarannya.

f. Faktor emosi dalam diri

Tidak semua bentuk sikap ditentukan oleh situasi lingkungan dan pengalaman pribadi seseorang. Kadang-kadang, suatu bentuk sikap merupakan pernyataan yang didasari oleh emosi yang berfungsi sebagai semacam penyaluran frustasi atau pengalihan bentuk mekanisme pertahanan ego. Sikap demikian bersifat sementara dan segera berlalu begitu frustasi telah hilang akan tetapi dapat pula merupakan sikap yang lebih persisten dan lebih tahan lama. contohnya bentuk sikap yang didasari oleh faktor emosional adalah prasangka. (www.duniapsikologi.com).

\section{Motivasi}

Motivasi adalah proses pengerahan intensitas, tujuan, dan kegigihan usaha seseorang terhadap pencapaian suatu tujuan (Robbins,2003:155). Ada beberapa alasan kenapa seseorang ingin menjadi pengusaha (entrepreneur). Secara umum yaitu karena ingin menjadi bos, mengikuti apa yang menjadi idenya, ingin mewujudkan mimpinya, untuk mendapatkan uang, karena punya tanggung jawab yang besar terhadap keluarga, dan lain sebagainya (Barringer, 2006:6).

\section{Konsep Kewirausahaan}

Soemanto (1989) dalam Hantoro (2005 : 23-37) berpendapat bahwa manusia wirausaha adalah orang yang memiliki potensi untuk berprestasi. Manusia wirausaha adalah manusia yang berkepribadian kuat dan memiliki ciri-ciri sebagai berikut :

a. Memiliki moral tinggi

Manusia yang bermoral tinggi setidaknya memiliki dan melaksanakan enam sifat utama, yaitu : ketaqwaan kepada Tuhan Yang Maha Esa, kemerdekaan batin, keutamaan, kasih saying terhadap sesama manusia, loyalitas hukum, dan keadilan.

b. Memiliki sikap mental wirausaha

Seseorang yang memiliki sikap mental wirausaha tinggi mempunyai kemauan keras untuk mencapai tujuan dan kebutuhan hidupnya. Disamping berkemauan keras, manusia yang bermental wirausaha memiliki keyakinan yang kuat akan kekuatan yang ada pada dirinya. Ketekuanan dan keyakinan inilah yang memberikan harapan, kegairahan, serta semangat untuk bekerja atau berbuat untuk mencapai tujuan-tujuan hidup. Manusia wirausaha juga memiliki mental yang jujur, kreatif, dan ulet untuk bekerja keras.

c. Memiliki kepekaan terhadap lingkungan

Kemampuan pengenalan terhadap lingkungan memungkinkan manusia dapat mendayagunakan sumber daya alam secara efisien untuk kepentingan hidup. Manusia hidup di dunia berkewajiban belajar dan bekerja keras agar dapat hidup sejahtera. Dengan belajar dan bekerja, manusia memperoleh kemajuan dan keberhasilan dalam hidup.

d. Memiliki ketrampilan wirausaha

Untuk menjadi manusia wirausaha yang tangguh diperlukan beberapa jenis ketrampilan diantaranya yaitu: ketrampilan berpikir kreatif, ketrampilan mengambil keputusan, ketrampilan dalam kepemimpinan, ketrampilan bergaul dan ketrampilan manajerial yang meliputi terampil dalam perencanaan, mampu memberikan dorongan dan motivasi kerja, mengkoordinasikan pelaksanaan tugas dan pekerjaan, mengawasi pekerjaa, serta mengadakan penilaian secara terus menerus. 
Sedangkan Timmons (1985) dalam Winardi (2005:40) berpendapat bahwa karakteristik entrepreneur sudah dimiliki seseorang sejak lahir. Adapun karakteritik tersebut sebagai berikut :

a. Enerji tanpa batas, kesehatan prima, dan stabilitas emosional

Para entrepreneur menghadapi aneka macam tantangan yang menuntut adanya enerji fisikal hebat dan enerji emosional yang mantap

b. Kreativitas dan kemampuan untuk bertindak inovatif

Kemampuan untuk menciptakan ide-ide baru, konsep-konsep baru, dan cara-cara baru untuk memandang masalah-masalah.

c. Intelegensi tinggi dan kemampuan konseptual Para entrepreneur yang berhasil merupakan kelompok pemikir strategis yang baik.

\section{Faktor-Faktor yang Mempengaruhi Minat Kewirausahaan}

Intensi kewirausahaan dapat dipengaruhi oleh faktor kepribadian dan lingkungan. Faktor kepribadian terdiri dari need for achievement, locus of control, dan self-efficacy. Seseorang yang memiliki keinginan yang kuat untuk berprestasi biasanya mengapresiasikan tanggungjawab per-Isonal dan menyukai risiko serta memiliki keinginan yang kuat untuk memperoleh hasil dari keputusan yang dia buat. Seseorang yang memiliki keinginan yang kuat untuk berprestasi lebih percaya diri. Locus of control mengacu pada persepsi individu tentang kesuksesan dan kegagalan. Seseorang yang memiliki pengendalian yang tinggi cenderung memiliki visi yang jelas dan rencana bisnis jangka panjang. Semakin tinggi locus of control maka semakin tinggi intensi kewirausahaan seseorang. Self efficacy merupakan keyakinan seseorang terhadap kemampuannya untuk menyelesaikan pekerjaan atau tugas yang dibebankan kepadanya. Persepsi seseorang terhadap self-efficacy memiliki pengaruh yang kuat pada tindakan mereka dan bagaimana pengetahuan dan ketrampilan akan dimanfaatkan (Indarti, 2004 : 59-60).

Seseorang termotivasi akan sesuatu pasti disebabkan oleh beberapa faktor antara lain karena keuntungan-keuntungan yang akan mereka dapatkan setelah melakukan kegiatan tersebut. Tetapi perlu diingat bahwa selama pencapaian keuntungan tersebut pasti akan mengalami banyak kendala yang dihadapi. Oleh karena itu sebelum masuk pembahasan perlu adanya pengetahuan tentang keuntungan yang didapat dan kendala yang akan dihadapi. Berikut ini adalah pembahasan tentang keuntungan dan kendala dalam kewirausahaan berdasar pendapat .Zimmerer (2001: 6).

a. Keuntungan-keuntungan dalam dunia kewirausahaan

Sebelum mendirikan suatu bisnis baru setiap orang harus mempertimbangkan keuntungan - keuntungan mendirikan usaha kecil. Keuntungan - keuntungan tersebut adalah sebagai berikut :

1) Kesempatan untuk menciptakan tujuan sendiri

2) Kesempatan untuk membuat sebuah perbedaan

3) Kesempatan untuk mencapai potensi penuh

4) Kesempatan untuk mendapat keuntungan yang tak terbatas

5) Kesempatan untuk memberikan kontribusi bagi masyarakat

6) Kesempatan mengerjakan yang disukai

b. Kendala-kendala dalam dunia kewirausahaan

Kepemilikan bisnis kecil mempunyai banyak keuntungan tetapi juga akan muncul kendala yang akan dihadapi oleh setiap wirausaha. Oleh karena itu wirausaha harus mengantisipasi kendala yang dapat muncul sebagai berikut :

1) Ketidakpastian Pendapatan

2) Resiko kehilangan seluruh investasi

3) Kerja lama dan kerja keras 
4) Kualitas hidup rendah sampai bisnis mapan

5) Tingkat stress tinggi

6) Tanggung jawab penuh

7) Putus asa

Pertimbangan keuntungan dan kendala yang dapat muncul selama proses permulaan bisnis mempengaruhi motivasi seseorang dalam mengambil keputusan untuk menjadi wirausahawan. Seringkali young entreprenuers merasa putus asa pada saat menghadapi masamasa sulit saat permulaan usaha karena kendalakendala diatas muncul dalam bisnisnya.

\section{Peran Universitas dalam Pendidikan Kewi- rausahaan}

Peranan universitas dalam memotivasi para sarjananya menjadi young entrepreneurs merupakan bagian dari salah satu faktor pendorong pertumbuhan kewirausahaan. Ada 8 faktor pendorong pertumbuhan kewirausahaan menurut (Zimmerer,2001:12) antara lain yaitu:

a. Wirausahawan sebagai pahlawan

Faktor diatas sangat mendorong setiap orang untuk mencoba mempunyai usaha sendiri karena adanya sikap masyarakat bahwa seorang wirausaha dianggap sebagai pahlawan dan sebagai model untuk diikuti. Sehingga status inilah yang mendorong seseorang memulai usaha sendiri.

b. Pendidikan kewirausahaan

Pendidikan kewirausahaan sangat populer di banyak akademi dan universitas di Amerika. Banyak mahasiswa semakin takut dengan berkurangnya kesempatan kerja yang tersedia sehingga mendorong untuk belajar kewirausahaan dengan tujuan setelah selesai kuliah dapat membuka usaha sendiri.

c. Faktor Ekonomi dan kependudukan

Dari segi demografi sebagian besar entrepreneur memulai bisnis antara umur 25 tahun sampai dengan 39 tahun .Hal ini didukung oleh komposisi jumlah penduduk di suatu negara sebagian besar pada kisaran umur diatas.Lebih lagi, banyak orang menyadari bahwa dalam kewirausahaan tidak ada lagi pembatasan baik dalam hal umur,jenis kelamin, ras, latar belakang ekonomi atau apapun juga dapat mencapai sukses dengan memiliki bisnis.

d. Pergeseran ke ekonomi jasa

Di Amerika pada tahun 2000 sektor jasa menghasilkan $92 \%$ pekerjaan dan $85 \%$ GDP negara tersebut. Karena sektor jasa relatif rendah investasi awalnya sehingga menjadi populer di kalangan para wirausaha dan mendorong wirausaha untuk mencoba memulai usaha sendiri di bidang jasa.

e. Kemajuan Teknologi

Dengan bantuan mesin bisnis modern seperti komputer pribadi, laptop, mesin fax, printer berwarna, mesin penjawab telepon seseorang dapat bekerja di rumah seperti layaknya bisnis besar. Pada jaman dulu, tingginya biaya teknologi membuat bisnis kecil tidak mungkin bersaing dengan bisnis besar yang mampu membeli alat-alat tersebut. Sekarang komputer dan alat komunikasi tersebut harganya berada dalam jangkauan bisnis kecil.

f. Gaya hidup bebas

Kewirausahaan sesuai dengan keinginan gaya hidup orang Amerika yang menyukai kebebasan dan kemandirian yaitu ingin bebas memilih tempat mereka tinggal dan jam kerja yang mereka sukai. Meskipun keamanan keuangan tetap merupakan sasaran penting bagi hampir semua wirausahawan, tetapi banyak prioritas lain seperti lebih banyak waktu untuk keluarga dan teman, lebih banyak waktu senggang dan lebih besar kemampuan mengendalikan stres hubungan dengan kerja. Dalam penelitian yang dilakukan oleh Hotel Hilton, $77 \%$ orang dewasa yang diteliti, menetapkan penggunaan lebih banyak waktu dengan keluarga dan teman sebagai prioritas 
pertama. Menghasilkan uang berada pada urutan kelima dan membelanjakan uang untuk membeli barang-barang berada pada urutan terakhir.

g. E-Commerce dan The World Wide Web

Perdagangan online bertumbuh cepat sekali, yang menciptakan banyak kesempatan bagi wirausahawan berbasis internet atau Website. Data yang dikumpulkan menunjukkan bahwa 47 persen bisnis kecil melakukan akses internet sedangkan 35 persen sudah mempunyai Web sites sendiri. Faktor ini juga mendorong pertumbuhan wirausahawan di beberapa negara.

h. Peluang Internasional

Dalam mencari pelanggan, bisnis kecil kini tidak lagi dibatasi dalam ruang lingkup negara sendiri. Pergeseran dalam ekonomi global yang dramatis telah membuka pintu ke peluang bisnis yang luar biasa bagi para wirausahawan yang bersedia menggapai seluruh dunia. Kejadian dunia seperti tembok Berlin, revolusi di negara-negara Baltik Uni Sovyet dan hilangnya hambatan perdagangan sebagai hasil perjanjian Masyarakat Ekonomi Eropa, telah membuka sebagian besar pasar dunia bagi para wirausahawan. Peluang Internasional akan terus berlanjut dan tumbuh dengan cepat pada abad ke-21.

Faktor yang mendukung pembahasan ini adalah faktor Pendidikan Kewirausahaan. Di Amerika, banyak universitas mempunyai suatu program khusus dalam mempelajari bidang kewirausahaan sehingga ada suatu embrio young entrepreneurs. Peranan universitas hanya sekedar menjadi fasilitator dalam memotivasi, mengarahkan dan penyedia sarana prasarana dalam mempersiapkan sarjana yang mempunyai motivasi kuat, keberanian, kemampuan serta karakter pendukung dalam mendirikan bisnis baru.

\section{Kerangka Pemikiran}

Motivasi untuk berwirausaha dapat dipicu oleh persepsi mereka mengenai kewirausahaan. Persepsi kewirausahaan dapat dibentuk melalui pemberian wawasan atau pengetahuan mengenai kewirausahaan. Dalam mata kuliah kewirausahaan dibahas mengenai keuntungan-keuntungan berbisnis. Selain itu, permasalahan yang muncul dalam berwirausaha juga dijelaskan. Persepsi mengenai kewirausahaan tidak hanya muncul dari pengetahuan yang dipelajari tetapi juga dapat muncul karena mengamati lingkungan dunia usaha.

Motivasi berwirausaha dapat disebabkan oleh 2 (dua) faktor yang berkaitan dengan keuntungan-keuntungan dan kendala-kendala jika berwirausaha. Motivasi akan tinggi jika seseorang mempertimbangkan keuntungan-keuntungan yang akan didapatkan jika berwirausaha. Namun, motivasi berwirausaha rendah jika seseorang lebih mempertimbangkan risiko atau kendala yang harus dihadapi dalam berwirausaha.

Sikap seseorang untuk berwirausaha berawal dari motivasi dari mereka sendiri. Seseorang yang memiliki motivasi tinggi untuk berwirausaha diyakini memiliki sikap positif untuk berwirausaha. Dengan kata lain, seseorang yang termotivasi untuk berwirausaha akan merealisasikannya dalam sebuah sikap untuk bertindak menjadi seorang wirausaha.

\section{Gambar 1}

Model Penelitian

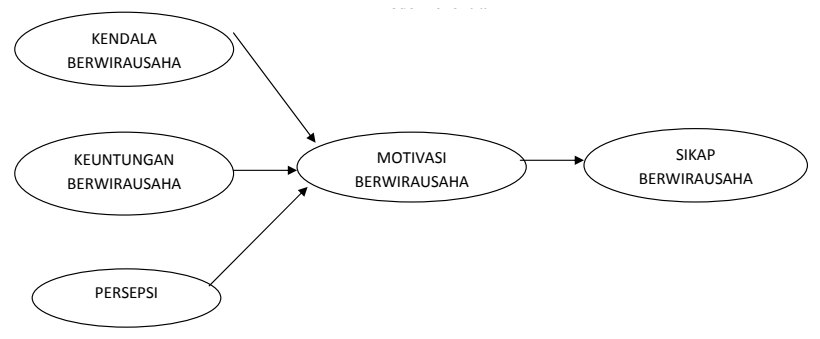




\section{METODE PENELITIAN}

Populasi penelitian ini adalah mahasiswa Program Studi Manajemen Fakultas Ekonomi Universitas Ahmad Dahlan Yogyakarta. Sedangkan sampel penelitian ini adalah mahasiswa yang telah menempuh mata kuliah Kewirausahaan di Program Studi Manajemen. Teknik sampling yang digunakan adalah purposive random sampling.

Data dianalisis dengan menggunakan metode Partial Least Square (PLS). Partial Least Square (PLS) adalah sebuah software yang dikembangkan untuk mengolah data menggunakan persamaan struktural, dan juga dapat digunakan untuk persamaan regresi linear. pendekatan PLS bersifat distribution free, yakni tidak mengasumsikan data harus berdistribusi tertentu. Data yang akan diolah dapat berupa data nominal, ordinal, interval, dan rasio. Menurut Ghozali (2005), PLS merupakan metode analisis yang powerfull karena tidak mengasumsikan data harus dalam skala pengukuran tertentu dan juga mengenai jumlah sampel relatif kecil (minimal direkomendasikan berkisar dari 30 sampai 100) (Ompusunggu, 2009).

\section{PEMBAHASAN DAN HASIL}

Karakteristik responden dijelaskan dalam beberapa aspek, yaitu pekerjaan orang tua, pengalaman kerja responden, jenis pekerjaan dan tingkat kepuasannya, serta pengalaman bisnis dan jenis bisnis yang pernah ditekuni responden. Mayoritas pekerjaan orang tua responden adalah wiraswasta yaitu sebesar $43,9 \%$, sedangkan PNS sebanyak $22 \%$, pegawai swasta dan guru masingmasing 7,3\%, sedangkan sisanya berprofesi sebagai petani, buruh, pensiunan dan ibu rumah tangga.

Dalam hal pengalaman kerja, sebanyak $22 \%$ responden sudah pernah bekerja. Jenis pekerjaan yang ditekuni antara lain: karyawan administrasi, sopir, kasir, shopkeeper, dan
SPG. Diantara responden yang sudah memiliki pengalaman kerja, hanya $2,4 \%$ responden yang merasa sangat puas dengan pekerjaannya, sedangkan yang puas dan kurang puas dengan pekerjaannya masing-masing sebanyak $9,8 \%$. Mayoritas responden, yaitu sebanyak 78\% merasa tidak puas dengan pekerjaannya.

Sebanyak 43,9\% responden sudah pernah melaksanakan praktek bisnis meskipun diantara mereka hanya melaksanakan pada acara-acara tertentu seperti economic fair yang diadakan oleh Fakultas Ekonomi.

Sebelum hipotesis diuji akan diuji terlebih dahulu convergent validity dari instrumen. Instrumen dinyatakan memenuhi convergent validity jika nilai original sample estimate di atas 0,5 dan nilai thitung di atas 1,96 . Berdasar outer loading pada kolom original sample estimate diperoleh angka di bawah 0,5 dan t hitung di bawah 1,96 pada PK4, PK5, PK7, dan KB5 .Dengan demikian perlu dilakukan pengujian model tahap kedua. Pada pengujian validitas tahap kedua diperoleh angka original sample estimate semuanya di atas 0,5 dengan t hitung lebih besar dari 1,96. Dengan demikian dapat dinyatakan model telah memenuhi convergent validity.

Hipotesis penelitian diuji menggunakan software PLS. Hipotesis diterima jika nilai $\mathrm{t}$ hitung lebih besar dari 1,96. Berdasar hasil estimasi diperoleh nilai t-statistik di atas 1,96 pada:

1. pengaruh persepsi mahasiswa akan kuliah kewirausahaan terhadap motivasi berwirausaha

2. pengaruh keuntungan berwirausaha terhadap motivasi berwirausaha

3. pengaruh motivasi terhadap sikap berwirausaha

Dengan demikian dapat dinyatakan bahwa hipotesis pertama, ketiga, dan kelima dapat diterima. 
Tabel 1

Hasil pengujian hipotesis

\begin{tabular}{lllll}
\hline & $\begin{array}{l}\text { original } \\
\text { sample } \\
\text { estimate }\end{array}$ & $\begin{array}{l}\text { mean of } \\
\text { subsamples }\end{array}$ & $\begin{array}{l}\text { Standard } \\
\text { deviation }\end{array}$ & T-Statistic \\
\hline persepsi -> motivasi & 0.469 & 0.487 & 0.148 & 3.174 \\
keuntungan -> & 0.285 & 0.341 & 0.123 & 2.320 \\
$\begin{array}{l}\text { motivasi } \\
\text { kendala -> motivasi }\end{array}$ & -0.337 & -0.272 & 0.179 & 1.882 \\
persepsi -> sikap & 0.141 & 0.147 & 0.104 & 1.355 \\
motivasi -> sikap & 0.789 & 0.779 & 0.090 & 8.741 \\
\hline
\end{tabular}

Sumber: hasil olah data

Hipotesis kedua dan keempat tidak terbukti karena nilai t-statistik lebih kecil dari 1,96. Dengan kata lain dapat dinyatakan bahwa tidak terdapat pengaruh yang signifikan antara persepsi akan kuliah kewirausahaan terhadap sikap berwirausaha mahasiswa (hipotesis kedua ditolak). Dan tidak terdapat pengaruh yang signifikan antara kendala berwirausaha terhadap motivasi berwirausaha (hipotesis keempat ditolak).

\section{Gambar 2}

\section{Hasil analisis jalur}

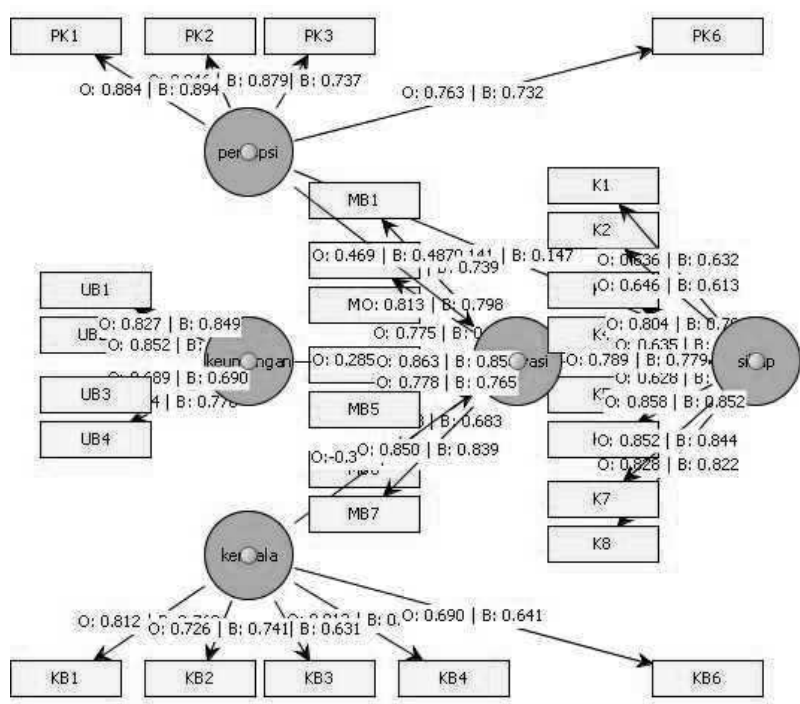

Hasil pengujian untuk rumusan masalah keempat sampai dengan keenam sebagai berikut: persepsi mahasiswa akan mata kuliah kewirausahaan masuk dalam kategori baik.
Dengan kata lain, mahasiswa memiliki persepsi yang baik tentang kuliah kewirausahaan baik dari aspek materi, penyampaian materi / cara penyampaian materi oleh dosen, tugas-tugas, dan kemampuan dosen.

Kesempatan untuk memberikan kontribusi bagi masyarakat merupakan keuntungan kewirausahaan yang paling banyak dipertimbangkan mahasiswa untuk berwirausaha. Sedangkan kesempatan untuk mendapat keuntungan yang tak terbatas merupakan keuntungan nomor 2 yang dipertimbangkan mahasiswa untuk berwirausaha.

Dalam hal kendala berwirausaha, tanggung jawab penuh terhadap bisnis merupakan kendala yang paling dikhawatirkan oleh mahasiswa untuk memulai bisnis. Sedangkan risiko kehilangan seluruh investasi merupakan hal kedua yang dikhawatirkan mahasiswa jika berwirausaha.

Hipotesis yang menyatakan bahwa terdapat pengaruh yang signifikan antara persepsi mahasiswa akan kuliah kewirausahaan terhadap motivasi berwirausaha dapat diterima. Persepsi yang baik mengenai perkuliahan dan proses belajar mengajar yang berkesan dapat menggugah motivasi mahasiswa untuk berwirausaha. Materi yang lengkap dan selalu mengikuti perkembangan zaman serta cara penyampaian materi yang menarik dapat menjadi salah satu cara membuat perkuliahan berkesan.

Keuntungan-keuntungan yang ditawarkan dunia usaha tentu akan menarik minat mahasiswa untuk berwirausaha. Dibandingkan dengan pekerjaan kantoran, dengan berwirausaha banyak keuntungan yang dapat diperoleh diantaranya adalah dapat mengatur waktu dengan lebih baik, memiliki kendali atas segala sesuatu, keuntungan yang tak terbatas, dan sebagainya.

Seseorang yang memiliki motivasi tinggi untuk berwirausaha tentu akan merealisasikannya dalam bentuk tindakan atau sikap. Sikap yang terlihat dari seseorang yang memiliki motivasi 
berwirausaha diantaranya adalah berpandangan positif mengenai kewirausahaan, mampu melahirkan ide bisnis, berani memulai usaha / bisnis, dan tidak sabar untuk segera berbisnis.

Hipotesis yang ditolak diantaranya yaitu mengenai pengaruh persepsi mahasiswa akan kuliah kewirausahaan terhadap sikap berwirausaha. Hasil ini membuktikan bahwa persepsi belum tentu dapat membentuk sikap untuk berwirausaha. Persepsi dipengaruhi banyak faktor, diantaranya lingkungan sekitar dan budaya. Mahasiswa yang memiliki budaya pekerja tentu dalam persepsinya akan terbentuk wacana bahwa bekerja akan aman jika bekerja pada sektor pemerintahan atau swasta. Budaya pekerja -diantaranya tidak menyukai risiko- tentu berbeda dengan budaya entrepreneur yang suka dengan risiko. Lingkungan dimana mahasiswa sering berinteraksi juga akan membentuk persepsi mereka mengenai kewirausahaan. Meskipun orangtua mahasiswa sebagian besar adalah wiraswasta ternyata belum tentu membentuk persepsi yang baik mengenai dunia usaha. Persepsi yang baik terbentuk jika lingkungan yang melingkupi mahasiswa adalah lingkungan wiraswasta yang sukses. Sebaliknya, lingkungan wiraswasta yang kurang sukses membuat mahasiswa berpersepsi kurang baik terhadap dunia usaha.

Kendala yang muncul didunia usaha juga tidak terbukti secara signifikan mempengaruhi motivasi berwirausaha. Kendala berwirausaha seperti risiko kehilangan investasi, waktu yang lama untuk meraih kesuksesan, dan keharusan untuk selalu fokus berbisnis ternyata membuat mahasiswa menjadi kurang tertarik untuk berwirausaha.

Penelitian ini memiliki keterbatasan dalam hal sampel. Sampel yang digunakan hanya mahasiswa yang telah menempuh mata kuliah kewirausahaan. Penelitian akan menjadi lebih lengkap jika menggunakan sampel dari alumni baik yang sudah bekerja atau yang sedang dalam proses mencari pekerjaan. Dengan demikian hasil penelitian mengenai dampak kewirausahaan terhadap motivasi dan sikap mahasiswa untuk berwirausaha menjadi lebih baik.

\section{KESIMPULAN DAN SARAN}

\section{Kesimpulan}

Berdasar analisis data, maka penelitian ini menyimpulkan bahwa :

1. Terdapat pengaruh yang signifikan antara persepsi mahasiswa akan kuliah kewirausahaan terhadap motivasi berwirausaha

2. Tidak terdapat pengaruh yang signifikan antara persepsi mahasiswa akan kuliah kewirausahaan terhadap sikap berwirausaha

3. Terdapat pengaruh yang signifikan antara keuntungan berwirausaha terhadap motivasi berwirausaha

4. Tidak terdapat pengaruh yang signifikan antara kendala berwirausaha terhadap motivasi berwirausaha.

5. Terdapat pengaruh yang signifikan antara motivasi terhadap sikap berwirausaha

6. Persepsi mahasiswa akan mata kuliah kewirausahaan masuk dalam kategori baik.

7. Kesempatan untuk memberikan kontribusi bagi masyarakat merupakan keuntungan kewirausahaan yang paling banyak dipertimbangkan mahasiswa untuk berwirausaha.

8. Tanggung jawab penuh terhadap bisnis merupakan kendala yang paling dikhawatirkan oleh mahasiswa untuk memulai bisnis.

\section{Saran}

Penelitian ini merumuskan beberapa saran, yaitu :

1. Perguruan tinggi harus menggiatkan aktivitas-aktivitas kewirausahaan di kalangan mahasiswa, karena terbukti dapat menumbuhkan motivasi untuk berwirausaha. Aktivitas-aktivitas yang dapat dilaksanakan diantaranya lomba kewirausahaan, seminar atau workshop kewirausahaan, serta aktivitas-aktivitas yang 
mendukung pengembangan softskill mahasiswa. Dengan demikian jiwa kewirausahaan sudah terbentuk sejak mahasiswa masih menempuh perkuliahan.

2. Perguruan tinggi juga perlu menjalin kerja sama dengan dunia usaha / UKM sehingga dapat menambah wawasan mahasiswa mengenai dunia usaha secara nyata. Kerjasama yang dikembangkan dapat berupa magang, KKN tematik, atau sekedar mendatangkan praktisi bisnis sebagai dosen tamu.

3. Untuk penelitian selanjutnya disarankan untuk dapat meneliti mengenai dampak kuliah kewirausahaan pada alumni perguruan tinggi baik yang sudah bekerja atau memiliki bisnis maupun yang masih mencari pekerjaan.

\section{DAFTAR PUSTAKA}

Darmadji, Ahmad. 2002. Pengaruh Tingkat Kemandirian Dan Motiyasi Berwiraswasta Terhadap Sikap Kewirausahaan Mahasiswa FIAI UII Yogyakarta. JPI FlAl. Volume VI Tahun V . Yogyakarta : Universitas Islam Indonesia

Ilyas, Supriyanto dan Gumilar, Ivan. 2011. Pengaruh Persepsi Mahasiswa Tentang Pendidikan Kewirausahaan Terhadap Kepercayaan Diri Dan Motivasi Mahasiswa Program Studi Akuntansi (Studi asus Pada Fakultas Ekonomi Universitas Widyatama). Thesis. Universitas Widyatama.

Indarti, Nurul. 2004. Factors Affecting Entrepreneurial Intentions Among Indonesia Students. Jurnal Ekonomi \& Bisnis Indonesia. Vol. 19, No.1. Yogyakarta : Univeristas Gadjah Mada.

Hantoro, Sirod. 2005. Kiat Sukses Berwirausaha. Yogyakarta : Adicita.
Hawadi, Reni Akbar, R. Sihadi Darmo Wihandjo, dan Mardi Wiyono. 2001. Keberbakatan Intelektual. Jakarta: Grasindo.

Modjo, Ikhsan, 2009, Peningkatan Angka Penganguran Di Tahun 2009 [Online]. Didapatkan: http: // www.seputarindonesia.com [6 Januari 2009].

Ompusunggu, Krisler Bornadi, 2009, Sekilas Tentang Partial Least Square [Online]. Didapatkan: http://anzbie86.wordpress. com [6 Januari 2009].

Robbin, Stephen P., and Mary Coulter, 2002, Management, Eight Edition, Pearson Education, Inc., Upper Saddle River, Prentice Hall, New Jersey, United States of America

Sugiyono. 2005. Metode Penelitian Bisnis. Bandung: Alfabeta

Suharyani, dan Moh Imam Teguh Rianto. 2003. Modul Pengolahan data Elektronik. Yogyakarta : Universitas Ahmad Dahlan

Sukardi. 2002. Hubungan Antara Persepsi Dan Sikap Siswa Terhadap Lingkungan Fisik Sekolah Dengan Prestasi Belajar Siswa Smu Negeri Di Kota Makassar. Tesis. Program Pascasarjana Universitas Negeri Makasar

Susanto, Eko. 2008. Pengertian Kreativitas [Online]. Didapatkan: http://eko13. wordpress.com/2008/03/16/pengertiankreativitas/[16 Maret 2008]

Tama, Angki Adi. 2010. Analisis FaktorFaktor Yang Memotivasi Mahasiswa Berkeinginan Menjadi Entrepreneur (Studi Pada Mahasiswa S1 Fakultas Ekonomi Universitas Diponegoro Semarang). Skripsi. Universitas Diponegoro Semarang

Zimmerer, W Thomas. 2001. Essentials of Entrepreneurshipand Small Business Management. Prentice Hall: Third Edition 
Zumar, 2008. Kepribadian Orang Kreatif [Online]. Didapatkan: http://pakzumar. blogspot.com/[8 April 2008]

http://www.infoskripsi.com/Theory/Teori-CaraPengukuran-Persepsi-MahasiswaTerhadap-Profesi-Pendidik.html. 29 okt 2012. Jam 14.35 http://www.duniapsikologi.com/sikappengertian-definisi-dan-faktor-yangmempengaruhi/29 okt 2012. Jam 15.00) 